\title{
Beef heifers grazing behavior and herbage intake in natural grassland under rotational grazing
}

\author{
Comportamento ingestivo e consumo de forragem de novilhas de \\ corte em pastagem natural manejada com pastoreio rotativo
}

\author{
Cezar Wankura Barbieri ${ }^{I}$ Fernando Luiz Ferreira de Quadros ${ }^{\mathrm{I}}$ Felipe Jochims ${ }^{\text {II }}$ \\ Bruno Castro Kuinchtner ${ }^{I}$ Thiago Henrique Nicola de Carvalho ${ }^{I}$ Pedro Trindade Casanova ${ }^{\mathrm{I}}$ \\ Augusto Miranda Fernandes ${ }^{I}$ João Bento Pereira ${ }^{I}$
}

\begin{abstract}
It was evaluated the effect of two rest intervals between grazing occupations in rotational grazing; 375 and 750 $D D$ (degree-days); based on the cumulative thermal sum necessary for leaf expansion of native grasses of two functional groups over the grazing behavior variables from beef heifers with 12 months old. The experiment was conducted as a completely randomized block design, with two treatments, three replications and measures repeated over time. Grazing behavior was assessed in three occasions (Nov 2011, Jan and Mar 2012), with 24h each. The herbage intake was estimated using an external marker $\left(\mathrm{Cr}_{2} \mathrm{O}_{3}\right)$. The leaf mass was similar among the rest intervals, with a mean of $1261 \mathrm{~kg} \mathrm{DM} \mathrm{ha} \mathrm{k}^{-1}$. The average grazing time was $627.4 \mathrm{~min}$ day ${ }^{-1}$ and bite rate was 37.1 bites $\mathrm{min}^{-1}$. The average number of daily meals was 5.9 with an average of 118.5 minutes. Number of feeding stations visited per minute was 6.1 and the feeding stations permanence time was of 12 seconds. There was a reduction only on grazing time and bite rate over the periods. The range of thermal sums evaluated to define the rest intervals in rotational grazing proved no effect on heifers' grazing behavior and herbage intake.
\end{abstract}

Key words: bite rate, degree-day, grazing time, sward structure, thermal-sum.

\section{RESUMO}

Foram testados os efeitos de dois intervalos de descanso entre pastoreios, 375 e 750 graus-dia, baseado na soma térmica para a expansão foliar de gramíneas nativas de dois grupos funcionais sobre o comportamento ingestivo de novilhas de corte. O delineamento foi em blocos ao acaso, com dois tratamentos, três repetições de área e medidas repetidas no tempo. Foram realizadas três avaliações (nov/11, jan e mar/12), com $24 \mathrm{~h}$ cada, utilizando novilhas de corte com 12 meses. Estimou-se o consumo de forragem com marcador externo $\left(\mathrm{Cr}_{2} \mathrm{O}_{3}\right)$. A massa de lâminas foliares foi semelhante entre os tratamentos, apresentando média de $1261 \mathrm{~kg} \mathrm{MS} \mathrm{ha-1}$. O tempo médio dispendido pelos animais em pastejo foi de 627,4 minutos e a taxa de bocados média foi de 37,1 bocados minuto ${ }^{-1}$. O número médio de refeições foi de 5,9 refeições dia ${ }^{-1}$, com uma média de 118,5 minutos por refeição. Os animais visitaram, em média, 6,1 estações alimentares por minuto e permaneceram nessas estações por 12 segundos. Houve diferença no tempo de pastejo e taxa de bocado nos períodos, com uma redução ao longo do tempo. Os intervalos de descanso testados provaram ter pouco efeito no comportamento ingestivo e no consumo de forragem das novilhas.

Palavras-chave: estrutura da pastagem, graus-dia, soma térmica, taxa de bocados, tempo de pastejo.

\section{INTRODUCTION}

Most of beef livestock production on South Brazil uses natural grasslands as the main source of food. The Pampa Biome occupies 62.2\% of Rio Grande do Sul state territory (CORDEIRO \& HASENACK, 2009) and feed around 18,8 million ruminants (IBGE, 2012) indicating their economical and social relevance for that region, although eventually present low productive performance.

Lower animal productivity observed when natural grassland is the feed basis can be attributed to the lack of knowledge about management of these environments (NABINGER et al., 2009), mostly by their great species diversity. Due to this high complexity, management of these grasslands becomes a challenge. In this way, to simplify its

\footnotetext{
'Laboratório de Ecologia de Pastagens Naturais (LEPAN), Universidade Federal de Santa Maria (UFSM), Santa Maria, RS, Brasil.

IEmpresa de Pesquisa e Extensão Rural de Santa Catarina (Epagri), Centro de Pesquisa para Agricultura Familiar (Cepaf), 89801-970, Chapecó, SC, Brasil. E-mail: felipejochims@epagri.sc.gov.br. Corresponding author.
} 
management, grass species were grouped according to morphogenetic characteristics and classified into four functional groups (EGGERS et al., 2004; CRUZ et al., 2010; MACHADO et al., 2013). Using grass species traits, QUADROS et al. (2009) proposed life elongation duration as a determinant time (in degrees days sum) in order to quantify the rest intervals between grazing for benefit specific different groups of plants. To become feasible the use of these plant characteristics or to explore these characteristics, rotational grazing should be used, mostly due to its control on duration and frequency of plants defoliation.

Recent research results have shown that the potential productivity of this management goes far beyond of what is usually recorded at commercial farms, making possible to obtain animal performance necessary to achieve 65 to $70 \%$ of adult weight, a goal for mating at 24 months of age (QUADROS et al., 2011; BARBIERI et al., 2014). Nevertheless, the influence of this management proposal (rotational grazing with rest intervals according to morphogenetic traits) on animal's behavior is not already explored.

The sward heterogeneity induces variations in grazing behavior, mostly due to high structural alternatives (CARVALHO et al., 2009), where animals need to find and access its food to meet their requirements of dry matter and nutritional intake. Strategies performed by animals that graze complex and heterogeneous swards are still not sufficiently evaluated (PINTO et al., 2007), mostly in rotational management, and studies considering the impact of grazing animals on natural resources and vice-versa became important tools to manage animals on natural grasslands.

The importance of understanding animals interactions with their environment is unquestionable. They provide information to be used as management goals to increase animal performance. Thus, the main objective of this research was to evaluate the effect of two rest intervals in a rotational grazing, based on two thermal sums for leaf elongation duration, on grazing behavior and herbage intake by beef heifers.

\section{MATERIAL AND METHODS}

The experiment was conducted in a natural grassland area, with bimodal height structure consisting of a mosaic of short (inter-tussock) and tall (tussock) grasses, at the Universidade Federal de Santa Maria (UFSM), Depressão Central region (RS), and $29^{\circ} 45^{\prime} \mathrm{S}, 5^{\circ} 45^{\prime} \mathrm{W}$ coordinates. The climate is humid subtropical (Cfa) according to Köppen classification. Soils in the experimental area belong to Santa Maria formation, classified as Planossolo Hidromórfico eutrófico (STRECK et al., 2008). During the experimental period (2011, November $7^{\text {th }}$ to April $\left.3^{\text {rd }}, 2012\right)$, the rainfall precipitation was lower than the normal precipitation (normal mean: $134.5 \mathrm{~mm} / \mathrm{month}$ ), with a mean of $80 \mathrm{~mm} /$ month. In Dec. 2011, no rainfall was recorded and the higher recorded precipitation was in February 2012, with $200 \mathrm{~mm}$. Mean temperature was two degrees above the normal mean $\left(22.4^{\circ} \mathrm{C}\right.$ during the trial; (normal mean: $20.1^{\circ} \mathrm{C}$ ).

The experimental area had 22.5ha, where the two treatments and three area replicates were distributed, totalizing six experimental units (paddocks). The treatments were two rest intervals in the rotational grazing, 375 and 750 degree-day sum (DD), defined by the accumulated thermal sum for the average leaf elongation duration of two functional grass groups, classified according to Cruz et al., (2010). Rest period between occupations of the $375 \mathrm{DD}$ is based on the time (in degrees-sum) for elongation of 2.5 leaves per tiller of functional types A and B (EGGERS et al., 2004). The 750 DD rest interval is based on the time for elongation of 1.5 leaves per tiller of functional types $\mathrm{C}$ and $\mathrm{D}$ (MACHADO et al., 2013). The experimental units of the 375 DD had seven subdivisions and the 750 DD treatments had eight subdivisions. Each subdivision had 0.5 ha.

The accumulated thermal sum was calculated by the sum of mean daily temperatures, measured during the experimental period, using daily maximum and minimum mean temperature, divided by 2 . The climatic data was obtained with the National Meteorological Institute (INMET), in the meteorological station of Santa Maria, RS. The occupation period was defined by the division of the thermal sum of each treatment by the paddocks subdivision number, resulting in time, in Celsius degrees, of occupation of each subpaddock. For 375 $\mathrm{DD}$, it ranges from 2.7 to 3 occupation days and for $750 \mathrm{DD}$, it ranges from 4 to 4.8 days. Along the trial, 375 DD treatment performed 7.5 grazing cycles (19.6 days each cycle) and 750 DD treatment, 4.2 cycles (35.2 days by cycle).

The grassland was managed under rotational grazing and variable stocking rate.Twenty four Angus beef heifers were used as test animals, with mean initial age of 12 months and weight of $185.2 \pm 17.4 \mathrm{~kg}$, with four "test" heifers per replicate. For stocking rate adjustments, it was used "put-and-take" heifers, with the same age of the test-animals. Stocking rate (SR) was adjusted using the leaves proportion in the sward, 
so that the calculated SR could remove $70 \%$ of the leaf mass and keeping a residual mass of $1500 \mathrm{~kg} \mathrm{DM} \mathrm{ha}^{-1}$ (QUADROS et al., 2011). This residual mass was used considering a "La Niña" forecast for the experimental period. Besides that, for SR adjustment it was considered a herbage disappearance of $4.5 \%$ of body weight (HERINGER \& CARVALHO, 2002). From February $2^{\text {nd }}$, until the end of the trial, the protocol was changed, due to favorable rainfall conditions. In this occasion, estimated herbage disappearance changes from 70 to $100 \%$ of leaf removal, which were above $1500 \mathrm{~kg} \mathrm{DM} \mathrm{ha}{ }^{-1}$. Water and mineral supplements were provided ad libitum.

Previously to the trial onset, six subdivisions, one by replicate, were elected as representatives of the paddock area. The herbage evaluations were carried out in those subdivisions assuming that those areas had similar vegetation and structure that the hole paddock. Thus, the herbage mass (HM) was measured using a visual standard comparison, calibrated with double sampling technique (HAYDOCK \& SHAW, 1975), with 20 visual estimates and six cuts by subdivision at ground level, using a $0.25 \mathrm{~m}^{2}$ quadrat. In each cut two subsamples were separated, one to determine the dry matter (DM) content and other to determine leaves, stems (of grass), dead material and other species (than grass) dry matter contribution in the sward.

The grazing behavior was evaluated when the animals were on the second occupation day of the subpaddock, in the following dates: November $18^{\text {th }}$, 2011, January $16^{\text {th }}, 2012$ and March $24^{\text {th }}, 2012$. It was measured the grazing, rumination and other activities time, along the $24 \mathrm{~h}$ of the day, each 10 minutes interval. The time spent by animals for herbage selection and apprehension, including the time in the displacement to select a new feeding station was considered as grazing (HODGSON, 1990). The rumination time was identified by the absence of grazing activity and by visual identification of mandibular movements. Time spent in other activities was considered the time when animals were not grazing or ruminating.

Bite rate was measured as the time necessary for the animal to accomplish 20 bites, transformed into bite/min, according to Jamieson and Hodgson (1979). The feeding stations and the displacement between them were measured by direct count, with observation of the number of steps and the time between two feeding stations, as well as the time necessary for 10 feeding stations utilization (RUYLE \& DWYER, 1985). The feeding stations visited per minute, the time spent in each feeding station and the number of steps between feeding stations were calculated. Besides that, it was counted the number of meals along the day, defined as a continuum grazing time, without interruptions of two or more assessments (20 minutes).

The herbage intake was measured on two occasions (December 09 ${ }^{\text {th }}, 2011$ and March $12^{\text {th }}, 2012$; period 1 and 3 ), using two animals by replicate, with $\mathrm{Cr}_{2} \mathrm{O}_{3}$ (chromium oxide). The period for adaptation and collection of feces samples comprised 10 consecutive days. $\mathrm{Cr}_{2} \mathrm{O}_{3}$ was provided orally, once a day (KOZLOSKI et al., 2006), in the morning to avoid thermal discomfort for the animals (7:30), together with a polyethylene external marker, with different colors for each animal to identify the feces. For ten consecutive days, animals were given $5 \mathrm{~g}$ of $\mathrm{Cr}_{2} \mathrm{O}_{3}$ and in the last three days the fecal samples were collected. The $\mathrm{Cr}_{2} \mathrm{O}_{3}$ provision started when animals were moving into the representative paddocks. For collections, daily "sweeps" were performed. If the polyethylene marker was present, samples were collected. The collected samples were dried until constant weight, macerated to remove the polyethylene markers and grounded.

Samples of $0.5 \mathrm{~g}$ was weighed and incinerated in a muffle at $600^{\circ} \mathrm{C}$ for three hours for $\mathrm{Cr}_{2} \mathrm{O}_{3}$ determination. Afterwards, $5 \mathrm{ml} \mathrm{Cr}_{2} \mathrm{O}_{3}$ digestion solution was added, according to CZARNOCKI et al. (1961) and placed in a hot plate at $220^{\circ} \mathrm{C}$. After the change in sample color (green to yellow), the content was filtered and transferred to a $100 \mathrm{ml}$ volumetric flask, completing the volume with distilled water to measure the $\mathrm{Cr}_{2} \mathrm{O}_{3}$ concentration by atomic absorption spectrophotometry. The standard curve was prepared with $100 \mathrm{mg} \mathrm{Cr}_{2} \mathrm{O}_{3}$ Fecal production (FP) was estimated as follows: $\mathrm{FP}=$ supplied $\mathrm{Cr}_{2} \mathrm{O}_{3}$ $\left(\mathrm{g} \mathrm{day}^{-1}\right) /$ feces $\mathrm{Cr}_{2} \mathrm{O}_{3}\left(\mathrm{~g} \mathrm{~kg}^{-1} \mathrm{DM}\right)$. Then, the intake estimation was calculated as follows: Intake ( $\mathrm{g}$ day $\left.^{-1}\right)=$ FP $\left(\mathrm{g} \mathrm{day}^{-1}\right) /(1$-digestibility $)$. The in situ digestibility of herbage samples apparently consumed by the animals, collected using EUCLIDES et al. (1992) methodology, was determined according to TILLEY \& TERRY (1963). These assessments were made when the animals were on the second day of occupation, during grazing behavior assessments. The hand plucking samples were analyzed for total $\mathrm{DM}$, in an oven at $105^{\circ} \mathrm{C}$, total nitrogen $(\mathrm{N} ; \mathrm{N} \times 6.25$ = crude protein; AOAC, 1990) and neutral detergent fiber (VAN SOEST, 1967).

The experiment was carried out as randomized block design, with repeated measures over time, two treatments and three replicates. The blocking criterion was the relief slope. Values were subjected to analysis of variance (ANOVA) using 
the CS covariance structure (Compound Symmetry), selected by the lowest AIC (Akaike's information criterion). The analysis was performed using SAS 9.2 software, with MIXED model procedure, including in the model the fixed effects of treatments, periods and the interaction treatment $\times$ period. Experimental error and blocks was the random effect. The means were adjusted by LSMEANS and compared by Tukey test, with $5 \%$ of significance level.

\section{RESULTS AND DISCUSSION}

The herbage mass (HM) in the 750 DD interval was $23.2 \%$ higher $(\mathrm{P}<0.05)$ than that measured in the 375 DD interval (3459 and $2656 \mathrm{~kg} \mathrm{DM} \mathrm{ha}^{-1}$, respectively) and similar over the experimental periods (mean of $3057 \mathrm{~kg} \mathrm{DM} \mathrm{ha} \mathrm{k}^{-1}$ from Nov. $11^{\text {th }}, 2011$ to Apr. 03 $\left.{ }^{\text {rd }}, 2012\right)$. No interactions were registered $(\mathrm{P}>0.05)$. These high values of $\mathrm{HM}$ was due to mass evaluation, which includes all aboveground mass, including dead material and the non-preferred plants (e.g. tussocks). Anyway, the HM in this experiment was higher than the HM considered detrimental for herbage intake of animals on natural grassland (GONÇALVES et al., 2009). The green leaf mass (GLM), where the heifers find the highest nutrient concentration and an architecture that facilitate the intake (CARVALHO et al., 2009) was similar between the rest intervals, with a mean of $1263 \mathrm{~kg} \mathrm{DM} \mathrm{ha}{ }^{-1}$ (Table 1). About the periods, the last period showed about $76 \%$ more leaves than the mean of the first two periods. Despite that, in any moment, the GLM was below the reference values in literature considering an optimized herbage intake and the herbage allowance (GONÇALVES et al., 2009; MEZZALIRA et al., 2012).

No interactions behavior variables $\times$ periods were found (Table 1). No differences were observed to grazing time between the rest intervals $(\mathrm{P}>0.05)$, with a mean of $627 \mathrm{~min} /$ day, similar to values observed by TRINDADE et al. (2012), in trials with $12 \%$ herbage allowance, which leads to the better animal performance in natural grasslands. Along with these findings, the grazing time was lower than recorded in limiting herbage allowance conditions (mean 710min day ${ }^{-1}$; $4 \mathrm{~kg}$ DM $100 \mathrm{~kg}^{-1} \mathrm{LW}$ ). Grazing time only changed over the periods $(\mathrm{P}<0.05)$.

The high grazing time values (mean of $665 \mathrm{~min}$ day $^{-1}$ ) in the first two evaluations, $20.1 \%$ higher than the last (553 $\left.\mathrm{min} \mathrm{day}^{-1}\right)$, was probably due to sward characteristics (Table 1), which was influenced by water deficit at beginning of the trial. As the searching time was included in the total grazing time, the time spent selecting and searching for food increased the grazing time. Reduction of the grazing time in the last period could be attributed to an increase in the NDF levels (from 76.1 to $77.2 \%$ ) due to the change from vegetative to reproductive cycle, the grazing time was replaced by the rumination activity. Behavior variables are time-dependent and, with an increase in one activity, other activity will reduce (CARVALHO et al., 2001).

The rumination time was similar among the rest intervals, with a mean of $501 \mathrm{~min}$ day $^{-1}$. Evaluations showed differences only for periods $(\mathrm{P}<0.05)$, being lower in the first and higher in the last evaluation. A decrease in grazing time along the evaluations was observed simultaneously with an increase of $20.1 \%$ in the time spent ruminating. This activity can occupy around eight hours a day, with variations between four to nine hours and is proportional to the feed fiber content (VAN SOEST, 1994). Along the phenological stages, there was an increase in the participation of stems and flowering stems in the sward (Table 1), increasing the NDF content, which increased rumination time. Time spent in other activities was similar between the rest intervals, with a mean of $311 \mathrm{~min}$ day $^{-1}$. Other activities had little influence, regardless the management, especially because this behavior variable is independent of the nutritional aspects (CARVALHO et al., 2001).

The number and duration of meals showed no significant differences for rest intervals or evaluations, presenting a mean number of 5.9 meals with 118.5 minutes of duration in each meal. MEZZALIRA et al. (2012), evaluating daylight animal behavior at different herbage allowances, observed in the considered best treatment (12\% herbage allowance), 4.9 meals per day and 136 minutes per meal. The difference of one meal and the shorter time by meal of the present study was probably due to the evaluation duration (24h). Still, in agreement with CARVALHO \& MORAES (2005), in swards with non-limiting herbage allowance, animals present a higher number of meals and, in each, a shorter time, promptly filling their rumen.

Number of feeding stations was similar between the rest intervals and periods $(\mathrm{P}>0.05)$, with mean value of 6.1 feeding stations $\mathrm{min}^{-1}$. The time spent at each feeding station was also similar between the rest intervals and periods, with a 12 second (mean) by feeding station. The number of feeding stations and time spent are similar to values indicated by GONÇALVES et al. (2009) when the sward are managed to optimize animal's intake. As higher the herbage allowance, more time is spent 
Table 1 - Herbage mass, green leaf mass (in kg dry mass/ha), leaf allowance ( $\%$ of live weight), crude protein and neutral detergent fiber (NDF; in \%) content, time expend grazing, rumination and in other activities (Other Act.; in minutes day ${ }^{-1}$ ), number and duration of meal, feed station (Feeds $\mathrm{min}^{-1}$ ) by minute; duration of feed, in seconds; number of steps between feed stations; dry matter herbage intake, in percentage of live weight of beef heifers managed with different pasture rest intervals (Ri) and over the periods (Per) under rotational management of a natural grassland.

\begin{tabular}{|c|c|c|c|c|c|c|c|c|}
\hline & \multicolumn{2}{|c|}{---- Rest intervals (Ri) ---- } & \multicolumn{3}{|c|}{ 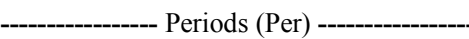 } & \multicolumn{2}{|c|}{ Significance effect $(\mathrm{P}=)$} & \multirow{2}{*}{$\mathrm{CV}$} \\
\hline & $375 \mathrm{DD}$ & $750 \mathrm{DD}$ & $1^{\text {st }}$ & $2^{\text {nd }}$ & $3^{\text {rd }}$ & $\mathrm{Ri}$ & Per & \\
\hline Herbage mass & $2656^{\mathrm{B}}$ & $3459^{\mathrm{A}}$ & 2840 & 2928 & 3405 & * & ns & 34.6 \\
\hline Green leaf mass & 1128 & 1393 & $1052^{\mathrm{B}}$ & $955^{\mathrm{B}}$ & $1775^{\mathrm{A}}$ & ns & $* *$ & 40.6 \\
\hline Stem mass & 305 & 446 & $254^{\mathrm{B}}$ & $425^{\mathrm{A}}$ & $447^{\mathrm{A}}$ & ns & $*$ & 56.3 \\
\hline Leaf herbage allow. & $13.9^{\mathrm{A}}$ & $9.3^{\mathrm{B}}$ & 12.3 & 12.8 & 11.3 & $*$ & ns & 31.3 \\
\hline Crude Protein & $9.6^{\mathrm{A}}$ & $8.0^{\mathrm{B}}$ & 9.3 & 8.4 & 8.8 & $* *$ & ns & 13.8 \\
\hline $\mathrm{NDF}$ & 76.9 & 76.2 & $76.4^{\mathrm{B}}$ & $76.1^{\mathrm{B}}$ & $77.2^{\mathrm{A}}$ & ns & $*$ & 1.6 \\
\hline Grazing time & 620 & 636 & $\begin{array}{c}\text { Grazing } \\
692^{\mathrm{A}}\end{array}$ & $\begin{array}{c}\text { or variab } \\
638^{\mathrm{A}}\end{array}$ & $553^{\mathrm{B}}$ & ns & $* *$ & 12.2 \\
\hline Rumination time & 514 & 488 & $441^{\mathrm{B}}$ & $510^{\mathrm{AB}}$ & $551^{\mathrm{A}}$ & ns & $*$ & 14.9 \\
\hline Other Act. Time & 306 & 316 & 307 & 292 & 336 & ns & ns & 16.9 \\
\hline Bite rate & 39.4 & 34.9 & $29.1^{\mathrm{B}}$ & $37.5^{\mathrm{AB}}$ & $44.9^{\mathrm{A}}$ & ns & $*$ & 26.6 \\
\hline Number of meals & 6.3 & 5.6 & 6.8 & 6 & 5 & ns & ns & 25.7 \\
\hline Duration of meals & 109.8 & 127.2 & 111.9 & 117.8 & 125.7 & ns & ns & 23.9 \\
\hline Feeds/min & 6.2 & 6.0 & 6.9 & 6.1 & 5.3 & ns & ns & 32.7 \\
\hline Dur. of feed (sec) & 11.7 & 12.3 & 10.0 & 12.6 & 13.3 & ns & $\mathrm{ns}$ & 38.0 \\
\hline Steps feed & 2.1 & 1.6 & 1.5 & 2.1 & 1.9 & ns & ns & 45.5 \\
\hline Herbage intake & 1.94 & 2.14 & 2.15 & - & 1.94 & ns & ns & 25.2 \\
\hline
\end{tabular}

${ }^{* *}<0.01 ;{ }^{*}<0.05, \mathrm{~ns}-$ non significate, $\mathrm{CV}-$ coefficient of variation.

by animals in the feeding stations, until they reach the "exit time", represented by the point at which the cost-benefit threshold is reached (lower bite mass), making the feeding station less interesting to the animal (CARVALHO et al., 2009). This theory demonstrates that the time spent at feeding stations in this trial indicates a non-limiting herbage allowance inside the feeding stations.

Another indicative of herbage availability in the feeding station is the number of steps between feeding stations. CARVALHO \& MORAES (2005) indicate that the higher herbage mass in the feeding station the higher is the number of steps between feeding stations, mostly due to the time for the animal to chew the herbage while searching another feed station. In this way, the number of steps between feeding stations was not different between the rest intervals (mean of 1.8 steps).

In addition, in well-managed natural grasslands animal's presents bite rates of 50 to 56 bites $\min ^{-1}$ (CARVALHO et al., 2009), increasing until more than 70 bites $\mathrm{min}^{-1}$ at restricted herbage allowance (DELAGARDE et al., 2001). Those values are higher than the bite rates observed in the rest intervals $(\mathrm{P}>0.05)$ of this study (mean of 37 bites $\mathrm{min}^{-1}$ ), indicating a "comfortable" situation to collect herbage in the treatments situation. Along the periods, the increase of $35 \%$ in the last period $(\mathrm{P}<0.05)$, together with the decrease of the grazing time, can be associated to changes in the sward structure, given by rainfall returning to usual in those period. With the increase of GLM, animals reduce the manipulative bites, increasing the bite rate and consequently reducing the grazing time. Anyway, despite those differences in bite rate, herbage intake was similar $(\mathrm{P}>0.05)$ between the rest intervals and along the periods.

Mean daily herbage intake was $2.04 \%$ of heifers mean body weight, totaling a mean of $4.2 \mathrm{~kg}$ dry mass herbage consumed by day. This intake was lower than results found by TRINDADE et al. (2012) under continuous grazing, even with higher herbage mass in this trial. The hypothesis drawn is that this intake difference is due to different sward structure among the experiments, due mostly to the grazing method used. 
Considering that all variables were similar $(\mathrm{P}>0.05)$ among the two rotation intervals, it should be emphasized that this rejected the hypothesis that grassland structure due to different defoliation frequency changes grazing behavior. To control differences in herbage allowance, both treatments were, at the same occupation day, when herbage mass did not restrict animals selection. However, at this moment differences in sward structure (green leaf/ total herbage, tussocks height and width, senescent material were still attached to plants) still didn't affects animals' ingestive behavior. Then, the effects caused by the treatments were not successfully detected. Even in the "short" rotation (375 DD), the changes in the availability of leaves and sward structure on the paddocks only could be relevant after three occupation days.

The NDF level of the hand plucking samples increased over the periods. At the start of the trial, the NDF content was around $76 \%$ and at the end, $77.3 \%$. As previously mentioned, the NDF content increase explained the increase of rumination time. The crude protein content of samples showed a mean of $9 \%$. Along the trial, the crude protein content was never lower than the minimum (7\%) for fiber degradation by rumen microorganisms (VAN SOEST, 1994).

The similarity of grazing times along the treatments, $\left(628\right.$ minutes day $\left.^{-1}\right)$, the similarity of intake (2.04\% of live weight) and the high leaf herbage allowance point out that the stocking rate can be higher, in both treatments, mostly to optimize leaf harvest, preventing leaf senescence or herbage death by trampling and optimizing the productivity of the natural grassland.

\section{CONCLUSION}

The different rest intervals based on thermal sum in on the second occupation day of rotational grazing do not change heifers grazing behavior or herbage intake. The recorded grazing times and herbage intake indicates that heifers were managed in a non-limiting sward condition.

\section{ETHICS COMITTE AND BIOSECURITY}

The authors of the article entitled "Beef heifers grazing behavior and herbage intake in natural grassland under rotational grazing" declared, for all purposes, the project that gave rise to the present data has not been submitted for evaluation to the Ethics Committee of the Universidade Federal de Santa Maria, but were aware of the content of the Brazilian resolutions of the Conselho Nacional de Controle de Experimentação Animal (CONCEA)
$<$ http://www.mct.gov.br/index.php/content/view/310553.html $>$ if it involves animals. Thus, the authors assume full responsibility for the presented data and are available for possible questions, if they required by the competent authorities.

\section{REFERENCES}

ASSOCIATION OF OFFICIAL ANALYTICAL CHEMISTS (AOAC). Official methods of analysis. 14.ed. Washington, 1990. 1141p.

BARBIERI, C.W. et al. Sward structural characteristics and performance of beef heifers reared under rotational grazing management on campos grassland. American Journal of Plant Sciences, v.5, p.1020-1029, 2014. Available from: <http:// dx.doi.org/10.4236/ajps.2014.57114>. Accessed: Jun. 10, 2014. doi:10.4236/ajps.2014.57114.

CARVALHO, P.C.F.; MORAES, A. Comportamento ingestivo de ruminantes: bases para o manejo sustentável do pasto. In: CECATO, U.; JOBIM, C.C. (Org.). Manejo sustentável em pastagem. Maringá - PR: UEM, 2005. V.1, p.1-20.

CARVALHO, P.C.F. et al. Importância da estrutura da pastagem na ingestão e seleção de dietas pelo animal em pastejo. In: MATTOS, W.R.S. (Org.). A Produção animal na visão dos brasileiros. Piracicaba: FEALQ, 2001. p.853-871.

CARVALHO, P.C.F. et al. Consumo de forragem por animais em pastejo: analogias e simulações em pastoreio rotativo. In: $25^{\circ}$ SIMPÓSIO SOBRE MANEJO DA PASTAGEM - Intensificação de sistemas de produção animal em pastos, 2009. Piracicaba. Anais... São Paulo, Piracicaba FEALQ, 2009. p.61-94.

CORDEIRO, J.L.P.; HASENACK, H. Cobertura vegetal atual do Rio Grande do Sul. In: PILLAR, V.D.P. et al. (Ed.). Campos Sulinos, conservação e uso sustentável da biodiversidade. Brasília: MMA, Ministério do Meio Ambiente, 2009. Cap.23, p.285-299.

CRUZ, P. et al. Leaf traits as functional descriptors of the intensity of continuous grazing in native grasslands in the South of Brazil. Rangeland Ecology \& Management, v.63, n.3, p.350-358, 2010. Available from: <http://www.bioone.org/doi/abs/10.2111/08016.1>. Accessed: Sept. 11, 2011. doi: 10.2111/08-016.1.

CZARNOCKI, J. et al. The determinations of chromic oxide samples of feed and excreta by acid digestion and spectrophotometry. Canadian Journal of Animal Science, v.41, n.2, p.167-179, 1961. Available from: <http://dx.doi.org/10.4141/ cjas61-024>. Accessed: Jan. 25, 2012. doi: 10.4141/cjas61-024.

DELAGARDE, R. et al. Ingestion de l'herbe par les ruminants au pâturage. Fourrages, v.166, p.189-212, 2001.

EGGERS, L. et al. Phyllochron of Paspalum notatum FL. and Coelorhachis selloana (HACK.) in Natural Pasture. Scientia Agricola, v.61, p.353-357, 2014. Available from: <http://dx.doi. org/10.1590/S0103-90162004000400001>. Accessed: Apr. 05, 2014. doi: 10.1590/S0103-90162004000400001.

EGGERS, L. et al. Phyllochron of Paspalum notatum FL. and Coelorhachis selloana (HACK.) camus in natural pasture. Scientia Agricola, v.61, p.353-357, 2004. Available from: $<$ http://www.scielo.br/scielo.php?script=sci_arttext\&pid 
=S0103-90162004000400001>. Accessed: Aug. 25, 2009. doi:10.1590/S0103-90162004000400001.

EUCLIDES, V.P.B. et al. Avaliação de diferentes métodos de amostragem sob pastejo. Revista Brasileira de Zootecnia, v.21, n.4, p.691-702, 1992. Available from: < http://www.revista.sbz.org. br/artigo/index.php?artigo=724>. Accessed: Jan. 23, 2012.

HAYDOCK, K.P.; SHAW, N.H. The comparative yield method for estimating dry matter yield of pasture. Australian Journal of Agriculture and Animal, v.15, p.66-70, 1975.

HERINGER, I.; CARVALHO, P.C.D.F. Ajuste da carga animal em experimentos de pastejo: uma nova proposta. Ciência Rural, v.32, p.675-679, 2002. Available from: <http://www.scielo, br/scielo.php?pid=S0103-84782002000400021\&script $=$ sci arttext>. Accessed: Mar. 21, 2012. doi:10.1590/S010384782002000400021 .

HODGSON, J. Grazing management: science into practice. Harlow: Longman Scientific \& Technical, 1990. 200p.

IBGE (INSTITUTO BRASILEIRO DE GEOGRAFIA E ESTATÍSTICA). Banco de dados. Available from: $<$ http://www. ibge.gov.br/estadosat/temas.php?sigla $=$ rs\&tema $=$ pecuaria2012>. Accessed: Oct. 30, 2014.

KOZLOSKI, G.V. et al. Uso de óxido de cromo como indicador da excreção fecal de bovinos em pastejo: variação das estimativas em função do horário de amostragem. Ciência Rural, v.36, n.2, p.599-603, 2006. Available from: <http://www.scielo.br/scielo. php? script $=$ sci_arttext\&pid $=$ S0103-84782006000200037>. Accessed: May 12,2013.doi:10.1590/S0103-84782006000200037.

MACHADO, J.M. et al. Morphogenesis of native grasses of Pampa Biome under nitrogen fertilization. Revista Brasileira de Zootecnia, v.42, n.1, p.22-29, 2013. Available from: <http://www.scielo.br/ scielo.php?pid=S1516-35982013000100004\&script $=$ sci_arttext $>$. Accessed: Feb. 03, 2014. doi:10.1590/S1516-35982013000100004.

MEZZALIRA, J.C. et al. The ingestive behaviour of cattle in largescale and its application to pasture management in heterogeneous pastoral environments. Journal of Agricultural Science and Technology, v.2, p.909-916, 2012. Available from: <http://www. ufrgs.br/gpep/documents/artigos/2012/The $\% 20$ Ingestive $\% 20$ Behaviour\%20of\%20Cattle\%20in\%20Large-scale.pdf $>$. Accessed: Oct. 21, 2013.

NABINGER, C. et al. Produção animal com base no campo nativo: aplicações de resultados de pesquisa. In: PILLAR, V.D.P. et al. (Ed.). Campos sulinos, conservação e uso sustentável da biodiversidade. Brasilia: MMA, Ministério do Meio Ambiente, 2009. Cap.13, p.175-198.

PINTO, C.E. et al. Comportamento ingestivo de novilhos em pastagem nativa no Rio Grande do Sul. Revista Brasileira de Zootecnia, v.36, p.319-327, 2007. Available from: <http://www. scielo.br/pdf/rbz/v36n2/07.pdf $>$. Accessed: Oct. 20, 2011.

QUADROS, F.L.F. et al. A abordagem funcional da ecologia campestre como instrumento de pesquisa e apropriação do conhecimento pelos produtores rurais. In: PILLAR, V.D.P.; MÜLLER, S.C. (Ed.). Campos sulinos, conservação e uso sustentável da biodiversidade. Brasilia: MMA, Ministério do Meio Ambiente, 2009. Cap.15, p.206-213. Available from: <http://ecoqua.ecologia.ufrgs.br/arquivos/Livros/ CamposSulinos.pdf>. Accessed: Aug. 03, 2013.

QUADROS, F.L.F. et al. Utilizando a racionalidade de atributos morfogênicos para o pastoreio rotativo: experiência de manejo agroecológico em pastagens naturais do Bioma Pampa. Cadernos de Agroecologia/Revista Brasileira de Agroecologia, v.6, 2011. Available from: <http://www.aba-agroecologia.org.br/revistas/ index.php/cad/article/view/12716/7020>. Accessed: Oct. 15, 2012.

RUYLE, G.B.; DWYER, D.D. Feeding stations of sheep as an indicator of diminished forage supply. Journal of Animal Science, v.16, n.2, p.349-353, 1985.

SENAR (SERVIÇO NACIONAL DE APRENDIZAGEM RURAL). Diagnóstico de sistemas de produção de bovinocultura de corte no Estado do Rio Grande do Sul. Porto Alegre, 2005. 265p. (Relatório SENAR, SEBRAE, FARSUL).

STRECK, E.V. et al. Solos do Rio Grande do Sul. 2.ed. Porto Alegre: Emater/RS, 2008. 222p.

TILLEY, J.M.A.; TERRY, R.A. A two-stage technique of the in vitro digestion of forage crop. Journal British Grassland Society, v.18, n.2, p.104-111, 1963.

TRINDADE, J.K. et al. Forage allowance as a target of grazing management: implications on grazing time and forage searching. Rangeland Ecology \& Management, v.65, p.382-393, 2012. Available from: <http://www.bioone.org/doi/abs/10.2111/REM-D-11-00204.1>. Accessed: Apr. 18, 2013. doi:10.2111/REM-D-11-00204.1.

VAN SOEST, P.J. Development of a comprehensive system of feed analysis and its applications to forages. Journal of Animal Science, v.26, n.1, p.119-127, 1967.

VAN SOEST, P.J. Nutritional ecology of the ruminant. Cornel, Ithaca: Cornell University Press, 1994. 